M. Fredj ${ }^{1,2}$,

A. Hafsaoui ${ }^{1}$, Dr. Sc. (Tech.), Prof., Y. Khadri ${ }^{1}$, Dr. Sc. (Tech.),

R. Boukarm ${ }^{2}$
1 - Badji Mokhtar University, Annaba, Algeria,e-mail: fredj_ khiero@yahoo.com

2 - University Abderrahmane Mira, Bejaia, Algeria

\title{
INFLUENCE OF THE FAILURE SURFACE CHOICE ON THE SAFETY FACTOR VALUE DURING SLOPE STABILITY STUDIES
}

Purpose. The aim of our work is to study the influence of the failure surface choice on the factor of safety for openpit Phosphate mine case.

Methodology. To estimate the influence of failure surface, our study is focalized on the case of the real slope with complex geometry (Kef-Essnoun Mine), where an important sliding has happened. Firstly, the safety factor (FS) was calculated with Limit Equilibrium Method (LEM) and three non-circular potential surfaces were chosen. Secondly, calculation of the safety factor was performed through the Finite Difference Method (FDM). Finally, the different values of FS obtained for the failure surfaces were compared in order to find the closest approach to what happened in our study case.

Findings. The FDM is a useful tool for verification of LEM design due to precise calculation of the safety factor and a unique failure surface.

Originality. The originality of this work is to use two different approaches, LEM and numerical method (FDM), for analysing the slope stability design and the accuracy of this method in mining engineering field.

Practical value. This study illustrates that the results obtained by LEM in the cases (2) and (3) (FS $=0.920$ the minimum value) of failure surface are almost identical to those obtained using the FDM $(\mathrm{FS}=0.87)$, which reflects the reality of our case of study. On the other hand, in the case (1) LEM gives a contradictory result regarding that by FDM (FS = 4.345), the sliding does not happen (total stability). The close agreement between the two analysis methods indicates that the FDM can be used as a practical and meaningful verification of conventional LEM of complex slopes.

Keywords: critical surface failure, factor of safety, FDM, LEM, slope stability, Kef-Essnoun Mine

Introduction. Slope stability analyses are an important issue and delicate problem in mining and civil engineering. Although landslides may occur in many parts of the world, their consequences depend on the natural phenomena and human activities. Landslide triggering is caused by many major causal factors $[1,2]$, such as rain, slope height, earthquake, ground water pressure, and vibration induced by blasting.

The study of these stability analyses can be estimated by the determination of a safety factor value, which from the mechanical point of view represents the ratio of security against failure. Also, the safety factors depend on the assumed hypothesis in the failure surface choice. Hence, the latter has a great influence on the value of FS.

However, the detection of the shape (circular or non-circular) of this surface is more difficult in geotechnical engineering. In general, slope stability methods are appreciated through two approaches: the LEMs and the numerical methods.

The LEMs are based on determining the forces and mobilized strength applied over a slide surface in the rock or soil slope. But these methods have more disadvantages with the choice of failure surface being one among these problems. In the last decades, with the technological development of the computer, these numerical methods including FEM (Finite Element Method), FDM and DEM (Discrete Element Method) have been used to overcome the limitations in the LEM [3].

(C) Fredj M., Hafsaoui A., Khadril Y., Boukarm R., 2018
The FDM can capture the strain-stress behavior of the rock and thus eliminate formulated assumptions in the LEM to bring the undetermined static problem to a statically determined one. Moreover, the problem of the slip surface choice is resolved.

The purpose of these studies is to describe the influence of the failure surface choice on the value of the safety factor by two different methods (LEM and numerical methods) for an open-pit phosphate mine.

Analysis Methods. Limit Equilibrium Methods. LEMs are mostly used for slope stability studies. These methods consist in cutting the slope into vertical slices and solving the hyper-static system of the equilibrium forces applied [4]. Several variants introducing each simplifying resolution hypothesis can be used in the case of a circular slip surface (Ordinary method, Bishop simplified) or of any shape of the slip surface (Method of Janbu, GLE/Morgenstern-Price (GLE/M-P) and Spencer (Table 1) [5].

In this work, the stability of the slope was analyzed using the computer program SLIDE 2D version 6.009 by Rocscience (2011) [7] to determine the static factors of safety, without load dynamic.

Numerical Methods. The numerical methods are a powerful tool for solving many engineering problems.

The FDM is one of these methods. In our work, this analysis is performed through the Itasca software FLAC version 7.0 by Itasca (2011) [8], where the acronym is Fast Lagrangian analyses of Continua. In the FDM, the factors of safety were obtained by Technique of the Shear Strength Reduction (TSSR). 
The different methods of analyses which are most applicable [5, 6]

\begin{tabular}{|c|c|c|c|c|c|}
\hline \multirow{3}{*}{ Methods } & \multicolumn{3}{|c|}{ Equilibrium conditions } & \multirow{3}{*}{$\begin{array}{l}\text { Shape of } \\
\text { slip surface }\end{array}$} & \multirow{3}{*}{ Applications } \\
\hline & \multicolumn{2}{|c|}{ Force Equilibrium } & \multirow{2}{*}{$\begin{array}{l}\text { Moment } \\
\text { Equilibrium }\end{array}$} & & \\
\hline & Horizontal & Vertical & & & \\
\hline Ordinary & - & - & $\checkmark$ & \multirow[t]{2}{*}{$\begin{array}{l}\text { Only } \\
\text { circular slip } \\
\text { surfaces }\end{array}$} & $\begin{array}{l}\text { Non-homogeneous slopes. Quite accurate for total stress } \\
\text { analyses for circular slip surface. Low accuracy for effective } \\
\text { stress analyses of flat slopes with strong water pressures }\end{array}$ \\
\hline $\begin{array}{l}\text { Bishop } \\
\text { Simplified }\end{array}$ & - & $\checkmark$ & $\checkmark$ & & $\begin{array}{l}\text { Non-homogeneous slopes. More accurate for the ordinary method } \\
\text { for total stress analyses with large interstitial pressures }\end{array}$ \\
\hline $\begin{array}{l}\text { Janbu's } \\
\text { Simplified }\end{array}$ & $\checkmark$ & $\checkmark$ & - & \multirow{3}{*}{$\begin{array}{l}\text { Any shape } \\
\text { of slip } \\
\text { surfaces }\end{array}$} & $\begin{array}{l}\text { Non-circular slip surfaces. The computed value of the safety } \\
\text { factor is sensitive to the assumed inclinations of side forces }\end{array}$ \\
\hline GLE/M-P & \multirow[t]{2}{*}{$\checkmark$} & \multirow[t]{2}{*}{$\checkmark$} & \multirow[t]{2}{*}{$\checkmark$} & & \multirow{2}{*}{$\begin{array}{l}\text { An accurate procedure applicable to virtually all slope } \\
\text { geometries and soil profiles. Rigorous, well established } \\
\text { complete equilibrium procedure (GLE/M-Price's method). } \\
\text { Spencer's method is the simplest complete equilibrium } \\
\text { procedure for calculating the safety factor }\end{array}$} \\
\hline Spencer & & & & & \\
\hline
\end{tabular}

In TSSR, rock shear strength is gradually decreased by applying finite difference programs as long as the first indications of failure appear.

The TSSR has many advantages compared to other methods of analyses of slope stability. One of these benefits is that it does not need to define the path of the critical failure surface beforehand. Due to the evolution the computer systems (high-speed), this method is more popularly used today than before [9].

To examine slope stability through TSSR, modeling is carried out using a set of safety factors as trial and error. In this TSSR, slope stability is defined using rock strength characteristics as follows

$$
\begin{gathered}
C^{*}=\frac{1}{F^{*}} C \\
\varphi^{*}=\arctan \left(\frac{1}{F^{*}} \tan \varphi\right),
\end{gathered}
$$

where $C^{*}$ and $\varphi^{*}$ are rock reduced strength characteristics, (adhesion and friction angle) in proportion to the real mode $(C, \varphi)$.

Geology and Mine Description. Geology. The Djebel El-Onk mining field is one of the largest mineral deposits in the world. The site in question (Kef-Essnoun mine) is located on the southern flank of Djebel El-Onk cretaceous anticline. It is about $73.5 \mathrm{~km}$ in the south of the Tebessa province in the northeast of Algeria and about $21 \mathrm{~km}$ to the Algerian-Tunisian border (Fig. 1).

A series of three major faults of NNW-SSE direction passes through the deposit without causing essential deformations on the geometry of the layers [10]. On the other hand, in the Kef-Essnoun zone, elongated to the Northeast $\left(\mathrm{N} 75^{\circ} \mathrm{E}\right)$, soft, brittle tectonics resulted in an abrupt change in the dip of the strata with an almost sub-vertical dip to strongly inclined towards the SouthEast and sometimes the North-West (Fig. 2, $a$ ).

From the point of view of the current tectonic situation and activity, the geological structure of the deposit has not undergone any recent tectonic activity.
Mine Description. Fig. 2, a shows the opening of the Kef-Essnoun deposit which takes place from the side of hole $\mathrm{N}^{\circ} 28$ corresponding to the center of the deposit and has the following characteristics [11]:

1. Thickness of the covering layer (limestone-dolomitic) $40 \mathrm{~m}$.

2. Thickness of the phosphate layer $31.5 \mathrm{~m}$.

The pit is cut at $70 \mathrm{~m}$ depth and has an overall face angle of $60^{\circ}$, made up of three benches, $30 \mathrm{~m}$ in height with face angles of 75 to $85^{\circ}$ and 10 to $20 \mathrm{~m}$ in width [12].

Mass Wasting of Kef-Essnoun Mine. On September 8, 2007 at 5:00 a.m., upon sliding of the northeastern side of Kef-Essnoun mine, a large mass of rock got detached from the massif and fell completely (Fig. 2, b). Gadri et al (2015) [10] mentioned that the failure mode which occurred in the open pit (Kef-Essnoun mine) is a planar sliding localized along the layer of phosphate/marls.

The area covered by this sliding block is about 11 hectares with an average thickness of about $70 \mathrm{~m}$ (30.5 m of phosphate and $40 \mathrm{~m}$ of overlying land).

The sliding of the Kef-Essnoun mine is a real catastrophe, although no damage, neither human nor material, was recorded. The only consequences are:

1. Shutdown of the exploitation of the slipped zone, which represents more than $90 \%$ of the total production of the mine, over a prolonged period.

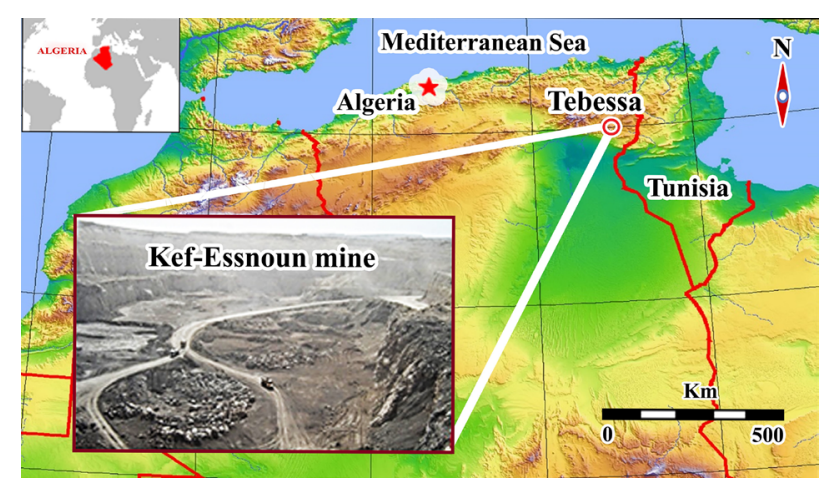

Fig. 1. Location map of the study area 


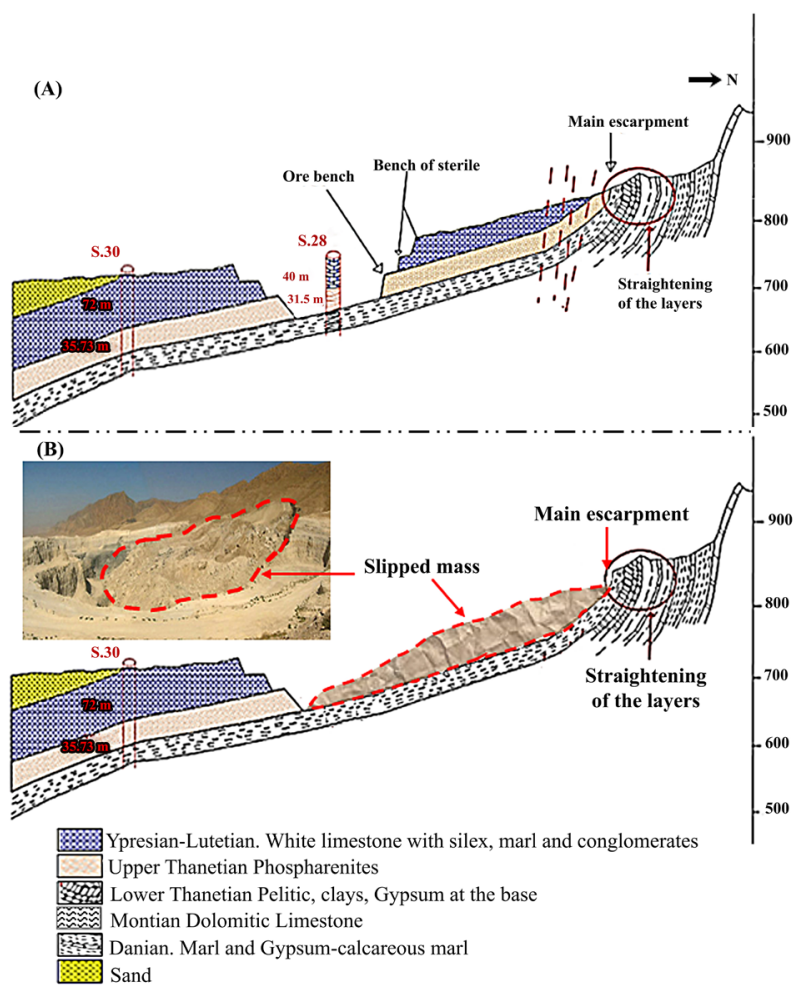

Fig. 2. Geological section of the studied slope (Kef-Essnoun mine):

$a$-after exploitation and before sliding; $b$-after sliding

2. The volume of the slippery mass is estimated at 7.7 million $\mathrm{m}^{3}$ filled with the entire open pit.

3. The volume of buried and abandoned reserves in the landslide zone (more than 3 million $\mathrm{m}^{3}$ ).

4. The exploitation trend turned to the west side of the open pit.

Location of the Surface Failure. The determination of the shape and location of the failure surface is an essential and indispensable step in characterizing a natural or anthropogenic landslide. For this sliding, the determination of the failure surface was easy.

Based on the North-South geological section of the slipped area (Fig. 2), the communicated documentation and the direct field observations, the characteristics of the sliding surface can be described as follows:

- the rock mass affected by the movement consists mainly of the exploited phosphate layer surmounted by marl limestone coverings;

- the observation of the shape of the slipped zone shows that the cover layer, consisting, in particular, of the limestones, has more or less retained its initial structure, which implies that the sliding surface is much deeper under this formation;

- the existence at the base of the phosphate layer of a Pelitic and clay formation of the lower Thanetian represents geomechanically a weak resistance compared to the phosphate layer;

- the main escarpment of the slip corresponds to the base of the phosphate level exploited (Fig. 2) and this base would coincide with the topographical dimension of the pit at the foot of the operated slope.
From the foregoing, it follows that the sliding surface corresponds to the phosphate/marl interface and that its shape follows the topography thereof, it would be a sliding guided by a stratigraphic plane inclined 14 to the south.

Methodology. To appreciate the influence of failure surface, our study is focalized on the case of Kef-Essnoun where an important sliding happened. Firstly, the safety factor was calculated and established with the LEM and three non-circular potential surfaces were chosen. Secondly, calculation of the safety factor through the FDM using TSSR was conducted with a unique failure surface imposed by the calculation technique. Finally, a comparison of the different values of FS obtained against failure surfaces was established in order to find the closest approach to what happened in our study case.

In this research, a typical cross-section of the KefEssnoun mine in eastern Algeria, with complex geometry was used as the case study. Boundaries, geometric conditions (materials) of the examined problem are all shown in Fig. 3 and were used as such in the following analyses with their respective geotechnical properties shown in Table 2.

As shown in Fig. 3, the phosphate layer is located between the limestone Ypresian-Lutetian intercalation layer and the marls.

These analyses were performed by both the LEM and FDM through the SLIDE ${ }^{\circledR}$ and FLAC ${ }^{\circledR}$ computer programs respectively to better understand a safety factor and the path of the critical failure surface.

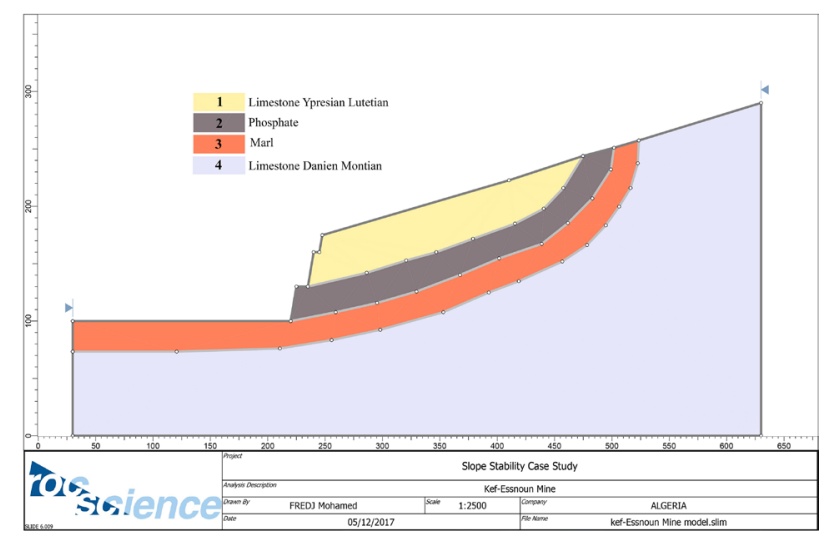

Fig. 3. Geometrical model used in SLIDE simulation

Table 2

Geotechnical parameters

\begin{tabular}{|c|c|c|c|c|c|c|}
\hline$\frac{n}{\pi}$ & $R_{c}$ & $\gamma_{d}$ & $E$ & $c$ & $\varphi$ & $\psi$ \\
\hline 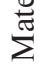 & (MPa) & $\left(\mathrm{kN} / \mathrm{m}^{3}\right)$ & $(\mathrm{kPa})$ & $(\mathrm{kPa})$ & $\left({ }^{\circ}\right)$ & $\left({ }^{\circ}\right)$ \\
\hline 1 & 58.84 & 27 & 27000 & 5400 & 37 & 7 \\
\hline 2 & 49.00 & 21 & 24000 & 2300 & 35 & 7 \\
\hline 3 & 9.58 & 23 & 1000.0 & 100.0 & 15 & 0 \\
\hline 4 & 19.17 & 27 & 27000 & 3600 & 37 & 7 \\
\hline
\end{tabular}

$R_{c}$ - Compressive Strength; $\gamma_{d}-d r y$ unit weight; $v$ - Poisson's ratio; $E-$ Young's modulus; $c$ - cohesion; $\varphi$ - friction angle; $\psi$ - dilatancy 
Results and Discussion. Analyses performed by SLIDE [7]. Slide 2D is a geotechnical computer software used to analyze different problems of slope instability, by calculating the safety factor of any shape of the failure surface a natural or artificial slope by the LEM.

In the LEM, the factors of safety were obtained by Spencer and GLE/M-Price's methods. For studying the influence of failure surface in rock slope stability, three potential surfaces were chosen in our case based of the observations after the sliding. The total number of the slip surface generated by block search is 5000 . The surface that has the minimum value of FS was taken as the critical surface failure.

Fig. 4 shows the different location of slip surfaces proposed. The output results of this slip surfaces are shown in Table 3. The minimum value of the safety factor is 0.920 .

The results obtained from the SLIDE analyses showed that the location of the surface failure has a strong influence on the safety factor.

As shown in Table 3 the safety factors varied between 4.345 (total stability for surface failure 1) to 0.920 instability and failure (surface failure 2). That finally indicates the importance of the choice of the path of failure (failure surface).

As a result, the accuracy of the use of the LEM depends essentially of failure surface choice. As mentioned by Hoek (2003) [13] 'The LEM suffers from the disadvantages that some form of predefined failure path must be assumed and that displacements in the slope are not taken into account'. These disadvantages can be overcome by using a numerical analysis method in which the progressive failure and deformation of the entire system can be simulated.

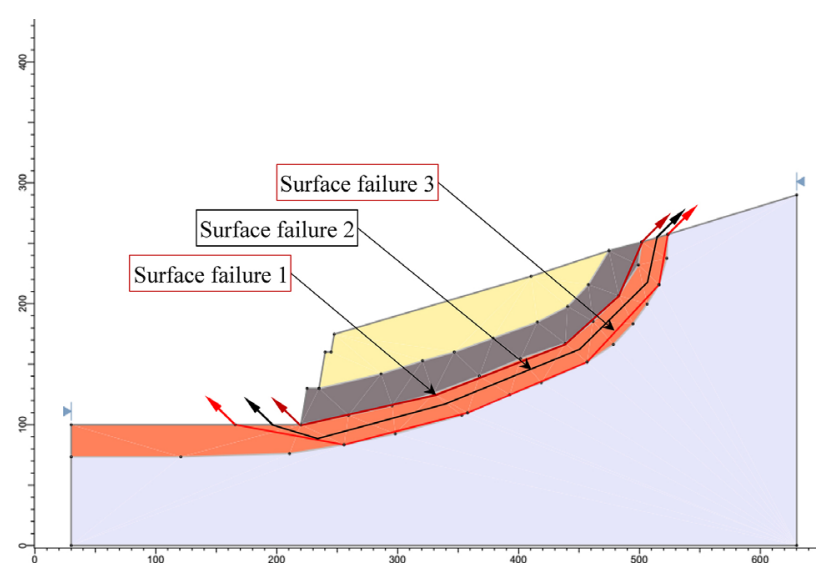

Fig. 4. Different location of the surfaces failure

Table 3

The safety factor computed from SLIDE for three cases

\begin{tabular}{|c|c|c|}
\hline \multirow{2}{*}{$\begin{array}{c}\text { Surface } \\
\text { failure }\end{array}$} & \multicolumn{2}{|c|}{ Safety Factor } \\
\cline { 2 - 3 } & Spencer & GLE/M-Price \\
\hline 1 & 4.359 & 4.345 \\
\hline 2 & 0.955 & 0.920 \\
\hline 3 & 1.022 & 0.979 \\
\hline
\end{tabular}

Analyses performed by FLAC [8]. The stability calculation was performed by using the TSSR. The geotechnical parameters used are presented in Table 2. Fine mesh (mesh density 150) is used Fig. 5.

The computed factor of safety was found at 0.87 . The localization of failure surface is shown in Fig. 6. Moreover, the FDM allows us to establish: displacements (Fig. 7), and plastic zones (Fig. 8).

The comparison of the safety factors obtained by the TSSR according to the Mohr-Coulomb criterion and

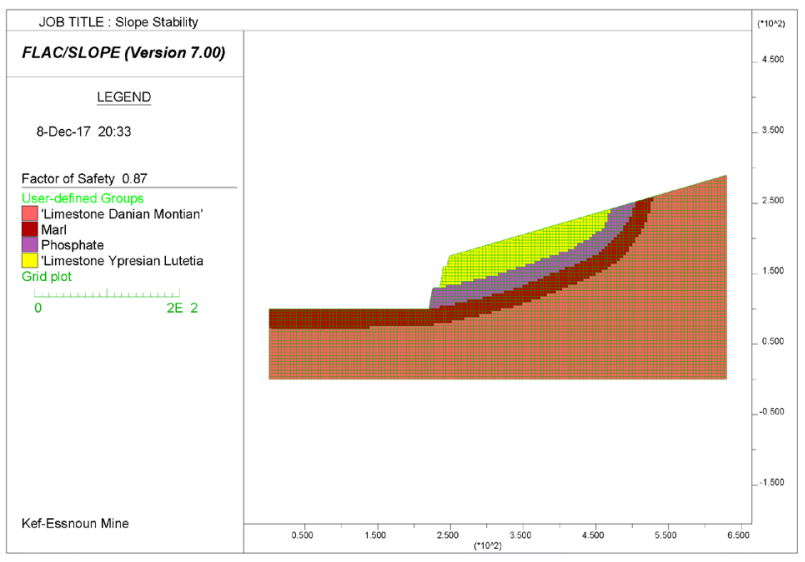

Fig. 5. Mesh plot showing stress and strain of quadrilateral elements from FLAC

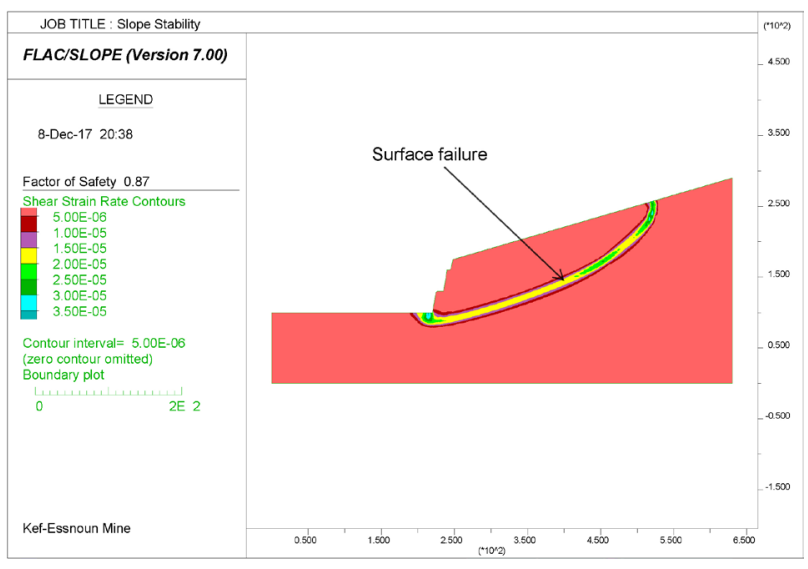

Fig. 6. Localization of failure surface and FS from FLAC

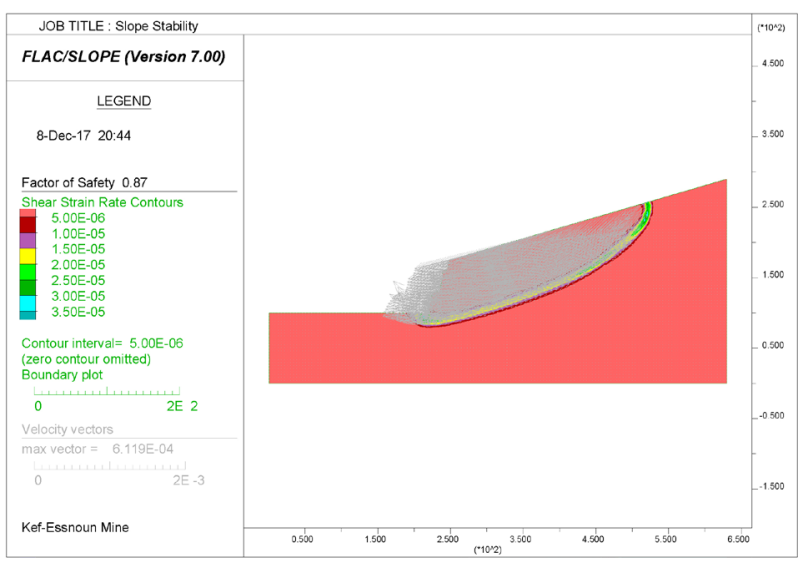

Fig. 7. Displacement direction plot from FLAC 
the LEM made it possible to extract the following points (Fig. 6 and Table 3):

- FS was under-estimated by about $9 \%$ compared to Spencer's;

- FS was over-estimated by about $5 \%$ compared to GLE/M-Price's.

The factor of safety found using the TSSR remains comparable with those found by the LEM.

The minimum value of the safety factor is less than $5 \%$ from that obtained by the LEM. However, the difference of computed factor of safety is relatively small. Additionally, the location of the failure surface is also close (Fig. 9).

Conclusions. This study has illustrated that the results of FS obtained by the LEM in the cases (2 and 3 ) of failure surface are almost identical to those obtained using the TSSR (FDM) that reflect the reality of our case of study. On the other hand, in case (1) the LEM gives a contradictory result regarding the FDM, with an error interval being very important, the slide did not happen. This margin of error is due to the accuracy which depends on the location of failure surface. However, the choice of the latter can influence the engineer in using the LEM these studies.

One important limitation of the conventional LEM is that it requires an arbitrary selection of the search areas and shape of the potential failure surfaces prior to analy-

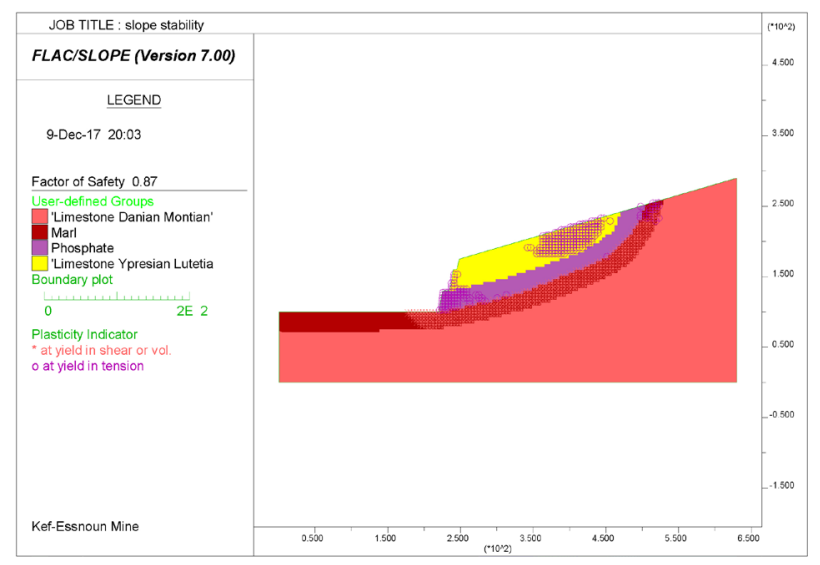

Fig. 8. Localization of plastic zones

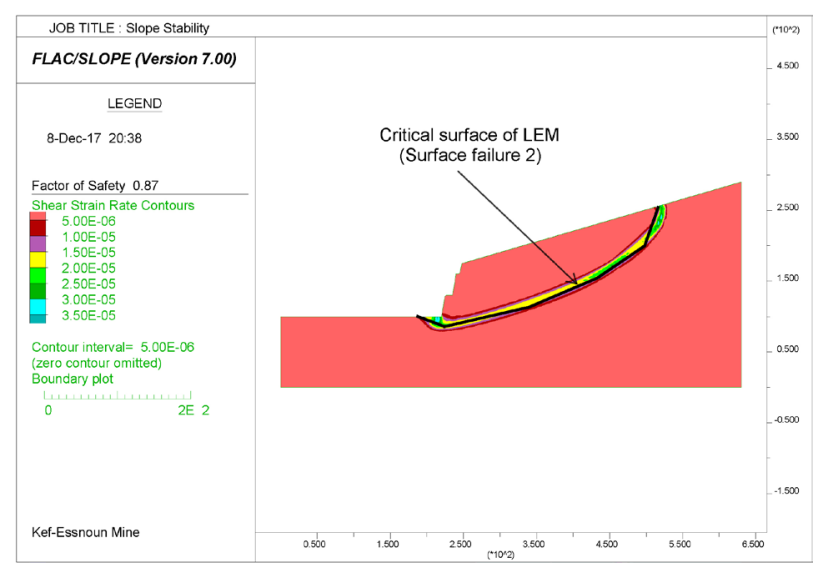

Fig. 9. Critical surface from LEM (surface failure 2) depicted on the shear strain from FDM ses. Accordingly, critical areas of the slope or critically shaped failure surfaces may be overlooked if the search areas and failure surface shapes are not well selected.

The FDM is a useful tool for verification of the LEM design due to precise calculations of the safety factor and a unique failure surface.

Recommendations. Using more than one method for analyses of existing or proposed slopes is the best approach for achieving reliable results.

Acknowledgments. The author would like to thank the staff of the natural resource and planning laboratory of Annaba University (Algeria). Also, special thanks to Professor A. Hafsaoui (Annaba University - Algeria) and Boukarm Riadh (Bejaia University - Algeria) for their objective comments and corrections.

\section{References.}

1. Chen, H.X., Zhang, L. M., Chang, D. S. and Zhang, S., 2012. Mechanisms and run out characteristics of the rainfall-triggered debris flow in Xiaojiagou in Sichuan province [J]. China Nat Hazards, 62, pp. 1037-1057.

2. Jeremy, R., 2014. Dynamic sensitivity analyses of long-running landslide models through basis set expansion and meta-modeling [J]. Nat Hazards, 73, pp. 5-22. 3. Tongchun, Li, Jinwen, He, Lanhao, Zhao, Xiaona, Li, and Zhiwei, Niu, 2015. Strength Reduction Method for Stability Analysis of Local Discontinuous Rock Mass with Iterative Method of Partitioned Finite Element and Interface Boundary Element. Mathematical Problems in Engineering, 2015, 11 pages. DOI:10.1155/2015/872834. 4. Krishna, A., Rolf, S. and Steinar, N., 2005-2006. Slope stability by limit-equilibrium and Finite Element Methods. In: Proceeding of the $16^{\text {th }}$ International Conference on Soil Mechanics and Geotechnical Engineering. pp. 2471-2476. DOI: 10.3233/978-1-61499-656-9-2471. 5. Baba, K., Bahi, L., Latifa Ouadif, L. and Akhssas, A., 2012. Slope Stability Evaluations by Limit Equilibrium and Finite Element Methods Applied to a Railway in the Moroccan Rif. Open journal of civil engineering. pp. 27-32. DOI: 10.4236/ojce.2012.21005.

6. Duncan, J.M., Wright, S.G. and Thomas, L. B., 2014. Soil Strength and Slope Stability. 2nd ed. Hoboken, New Jersey: John Wiley and Sons, Inc.

7. Rocscience Ltd., 2011. SLIDE-2D Slope Stability Analysis for Rock and Soil Slopes. Version 6.009. Toronto, Ontario, Available at: <www.rocscience.com/> [Accessed 14 February 2017].

8. Itasca Consulting Group Inc., 2011. FLAC (Fast Lagrangian Analysis of Continua), Version 7.00.411, Minneapolis, $\mathrm{MN}$.

9. Farshidfar, N. and Nayeri, A., 2015. Slope Stability Analysis by Shear Strength Reduction Method J. Civil Eng. Urban, 5(1), pp. 35-37.

10. Gadri, L., et al., 2015. The quarries edges stability in opencast mines: a case study of the Jebel Onk phosphate mine, NE, Algeria. Arab J Geosci, 8, pp. 8987-8997. 11. Mezam, M.C. and Assed, M.A. B., 2016. Etude Rétro-analytique du glissement du bord Nord de la mine à ciel ouvert de Kef Essnoun (Djebel Onk), Algérie. Bull Eng Geol Environ. 76, pp. 1307-1320. DOI: 10.1007/s10064-016-0988-X. 
12. Fredj, M., Youcef, K., Hafsaoui, A. and Menacer, K., 2017. Study of bench stability in the phosphate mine (Algeria). Engineering geology and geological engineering for sustainable use of the earth's ressources, urbanization and infrastructure protection from geohazards, sustainable civil infrastructures. DOI: 10.1007/978-3-319-61648-3_7.

13. Hoek, E., 2003. Analysis of the stability of an anchor block for a suspension bridge. EOAE External Report, Vancouver [online]. Available at: < https://www.rocscience.com/documents/pdfs/uploads/8051.pdf $>$ [Accessed 27 January 2017].

\section{Вплив вибору поверхні зламу на значення фактору міцності при дослідженні стійкості схилів}

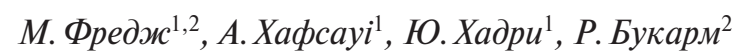

1 - Університет Баджі Мохтар, м. Аннаба, Алжир, e-mail: fredj_khiero@yahoo.com

2 - Університет Абдеррахмане Міра, м. Беджая, Алжир

Мета. Вивчити вплив вибору поверхні зламу на фактор міцності для відкритого фосфатного рудника.

Методика. Для оцінки впливу поверхні зламу дослідження проводиться на природному схилі зі складною геометрією (шахта Кеф-Ессну), де відбулося зсувне переміщення. Спочатку за допомогою методу граничної рівноваги (МГР) був визначений фактор міцності (ФМ) і були обрані три некругові потенційні поверхні. Потім розрахунок фактора міцності був проведений, використовуючи метод кінцевих різниць (МКР). На довершення порівнювалися різні показники ФМ, отримані на підставі наданих поверхонь зламу, з метою знайти найбільш прийнятний підхід до даної проблеми.

Результати. МКР є надійним способом підтвердження правильності МГР завдяки точності розрахунку фактора міцності та унікальної поверхні зламу.

Наукова новизна. Оригінальність даної роботи полягає у використанні двох різних подходів - МГР і чисельного методу МКР - для аналізу проектування стійкості схилу й точності даної методики в гірничій промисловості.

Практична значимість. Дослідження показує, що результати, отримані за допомогою МГР у випадках (2) i (3) (ФМ = 0,920 мінімальне значення) поверхні зламу, практично ідентичні тим, які отримані, використовуючи МКР (ФМ =0,87), що відображає дійсність даного дослідження. 3 іншого боку, у випадку (1) результати з МГР не відповідають МКР $(\Phi \mathrm{M}=4,345)$, переміщення не відбувається (повна стабільність). Узгодженість між двома методами аналізу вказує на те, що МКР може використовуватися як практичне й показове підтвердження традиційного МГР складних схилів.
Ключові слова: критичне поверхневе руйнування, фактор міцності, МГР, МКР, стійкість схилу, шахта Кеф-Ессну

\section{Влияние выбора поверхности излома на значение фактора прочности при исследовании устойчивости склонов}

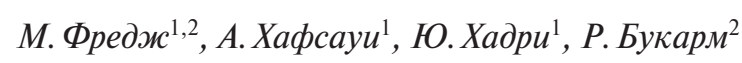

1 - Университет Баджи Мохтар, г. Аннаба, Алжир, e-mail: fredj_khiero@yahoo.com

2 - Университет Абдеррахмане Мира, г. Беджая, Алжир

Цель. Изучить влияние выбора поверхности излома на фактор прочности для открытого фосфатного рудника.

Методика. Для оценки влияния поверхности излома исследование проводится на естественном склоне со сложной геометрией (шахта Кеф-Эссну), где произошло оползневое перемещение. Сначала с помощью метода предельного равновесия (МПР) был определен фактор прочности (ФП) и были выбраны три некруговые потенциальные поверхности. Затем расчет фактора прочности был произведен, используя метод конечных разностей (МКР). В довершение сравнивались различные показатели ФП, полученные на основании предоставленных поверхностей излома с целью найти наиболее приемлемый подход к рассматриваемой проблеме.

Результаты. МКР является надежным способом подтверждения правильности МПР благодаря точности расчета фактора прочности и уникальной поверхности излома.

Научная новизна. Оригинальность данной работы состоит в использовании двух различных подходов - МПР и численного метода МКР - для анализа проектирования устойчивости склона и точности данной методики в горной промышленности.

Практическая значимость. Исследование показывает, что результаты, полученные с помощью МПР в случаях (2) и (3) (ФП = 0,920 минимальное значение) поверхности излома, практически идентичны тем, которые получены, используя МКР $(Ф П=0,87)$, что отражает действительность данного исследования. С другой стороны, в случае (1) результаты с МПР не соответствуют МКР (ФП = $=4,345$ ), перемещение не происходит (полная стабильность). Согласованность между двумя методами анализа указывает на то, что МКР может использоваться как практическое и показательное подтверждение традиционного МПР сложных склонов.

Ключевые слова: критичное поверхностное разрушение, фактор прочности, МПР, МКР, устойчивость склона, шахта Кеф-Эссну

Рекомендовано до публікації Аісса Бенселгуб. Дата надходження рукопису 11.05.17. 